\title{
RESPONSE OF TOMATO PLANTS TO POTASSIUM RATES AND CALCIUM SOURCES UNDER PLASTIC HOUSE CONDITIONS IN NORTH SINAI
}

\author{
Sara N. Awad ${ }^{1 *}$, E.M. El-Tantawy ${ }^{2}$ and N.M. Easa ${ }^{1}$ \\ 1. Ins. Hort. Res., Cen. Agric. Res., Cairo, Egypt. \\ 2. Dept. Plant Prod., Fac. Environ. Agric. Sci., Arish Univ., Egypt.
}

\begin{abstract}
Afield experiment was carried out under greenhouse conditions during the winter seasons of 2013-14 and 2014-15 at The Experimental Farm of the Faculty of Environmental Agricultural Sciences, Arish University, North Sinai Governorate, Egypt. The aim of this experiment was to study the effect of different $\mathrm{K}$ rates $\left(40,60\right.$ and $\left.80 \mathrm{Kg} \mathrm{K} \mathrm{K}_{2} \mathrm{O} / 540 \mathrm{~m}^{2}\right)$ and two sources of calcium; viz, Ca-chelate at $5 \mathrm{~g} \mathrm{l}^{-1}(0.5 \% \mathrm{Ca})$, Gurenkal at $5 \mathrm{ml} \mathrm{l}^{-1}(0.5 \% \mathrm{Ca})$ as well as the control treatment (without $\mathrm{Ca}$ ), with their interactions on growth, and yield of tomato (Solanum lycopersicon L.) hybrid V 59-48 under sandy soil conditions using drip irrigation system. A split plot design in three replicates was used. The results showed that treating tomato plants with calcium and potassium had significant and positive effects on almost studied traits of growth, and yield. The highest fresh and dry weight, as well as total yield of tomato plants were achieved when tomato plants fertilized with $80 \mathrm{~kg} \mathrm{~K} 2 \mathrm{O} / 540 \mathrm{~m}^{2}$ combined with Gurenkalat $5 \mathrm{ml} \mathrm{l}^{-1}(0.5 \% \mathrm{Ca})$ as foliar spray followed by $80 \mathrm{~kg} \mathrm{~K}_{2} \mathrm{O} / 540 \mathrm{~m}^{2}$ combined with Ca- chelate at $5 \mathrm{~g} \mathrm{l}^{-1}(0.5 \% \mathrm{Ca})$.
\end{abstract}

Key words: Tomato, greenhouse, potassium, calcium sources, fresh weight, marketable yield, and total yield.

\section{INTRODUCTION}

Tomato (Solanum lycopersicum L.) previously named (Lycopersicon esculentum Mill.) is an important vegetable crop in several parts of the world, including the regions suffering from drought and soil salinity, such as the Mediterranean region (Savic et al., 2009; Jensen et al., 2010). Tomato is widely used as salad as well as for cooking purposes. It is well known for its nutritional importance as it is the rich source of nutrients viz., $\mathrm{Na}, \mathrm{K}, \mathrm{Fe}$, vitamin $\mathrm{A}$ and $\mathrm{C}$, and antioxidants especially lycopene and salicylate (Afzal et al., 2013).

Potassium $(\mathrm{K})$ is the most efficient cation for tomato plants and according to several authors, it plays a key role in the improvement of several quality traits in tomato fruits and in almost all vegetables (Dorais et al., 2001; Chapagain and Wiesman, 2004; Cakmak, 2005). Potassium is one of the essential mineral nutrients in plant nutrition and one of the three which are taken up by roots from the soil solution in its ionic form. It is involved in numerous physiological processes that control plant growth, yield and quality parameters such as sugars, titratible acidity (TA), soluble solids (SS), total soluble solids (TSS), taste, color, firmness and meliness (Wuzhong, 2002; Lester et al., 2005). Potassium is a key nutrient for enhancing productivity of vegetable crops and its content in vegetables has significant positive relationship with quality attributes (Bidariand and Hebsur, 2011).

\footnotetext{
* Corresponding author: Tel.: +201090195239

E-mail address: saranageb.awad@yahoo.com
} 
Calcium is one of the most important mineral nutrients in greenhouse tomato production. A low supply of calcium to fruit leads to increase tomato fruit cracking (Simon, 1978) and blossom-end rot (Ho et al., 1999). Calcium deficiency in tomato reduces leaf size, causes necrosis of young leaves and yield loss in extreme cases (Adams and El-Gizawy, 1988; Holder and Cockshull, 1990). Calcium foliar spray increased the firmness of tomato fruit measured with and without the skin present (Garcia et al., 1995).

Involved in a wide range of processes in plants including flower induction (Friedman et al., 1989); reduced the incidence of BER (Hao et al., 2000). Calcium is an important nutrient that plays a key role in the structure of cell walls and cell membranes, fruit growth and development (Kadir, 2004); and fruit yield (Hao and Papadopoulos, 2004).

Calcium application increases growth; chlorophyll content, number of fruits per plant in tomato plants (Rady, 2012). So, the objectives of this work was to study the effect of potassium levels as soil application and two calcium sources as foliar application and their interactions on tomato plants grown under plastic house in sandy soil at El-Arish region.

\section{MATERIALS AND METHODS}

This study included a field study was carried out under greenhouse conditions during the winter growing seasons of 201314 and 2014-15 in The Experimental Farm of The Faculty of Environmental Agricultural Sciences, Arish University, North Sinai, Egypt to study the effect of three $\mathrm{K}$ rates $\left(40,60\right.$, and $\left.80 \mathrm{~K}_{2} \mathrm{O} \mathrm{kg} / 540 \mathrm{~m}^{2}\right)$, added as soil application and two sources of calcium; viz, Ca-chelate at $5 \mathrm{~g} \mathrm{l}^{-1}(0.5 \% \mathrm{Ca})$, Gurenkal at $5 \mathrm{ml} \mathrm{l}^{-1}(0.5 \% \mathrm{Ca})$ as well as the control treatment (without $\mathrm{Ca}$ ), with their interactions added as foliar application on tomato growth, and yield of tomato hybrid V 59-48 under sandy soil conditions.
Tomato seeds were sown in trays on $15^{\text {th }}$ October and transplanted 45 days later in both seasons of study. The plot area was $15 \mathrm{~m}^{2}$ (10 m length and $1.5 \mathrm{~m}$ wide), planting density was $2.22 \mathrm{plant} / \mathrm{m}^{2}$. Drip irrigation system was used, each plot had two dripper lines. The distance between each two dripper lines was $40 \mathrm{~cm}$, the distance between the plants in the same row was $50 \mathrm{~cm}$, while the distance between double dripper lines centers was $150 \mathrm{~cm}$. Potassium was added at three doses per week, while $\mathrm{Ca}$ was sprayed every two weeks.

The physical and chemical analyses of the experimental soil and irrigation water are presented in Tables 1 and 2.

This experiment included nine treatments which were the combination between three potassium rates $\left(40,60\right.$ and $\left.80 \mathrm{~kg} \mathrm{~K}_{2} \mathrm{O} / 540 \mathrm{~m}^{2}\right)$ and two calcium source; i.e., Ca-chelate at $5 \mathrm{~g}^{-1}(0.5 \% \mathrm{Ca})$, and Gurenkal at $5 \mathrm{ml}^{-1}$ $0.5 \% \mathrm{Ca}$ ) in addition to control treatment. The experimental treatments were randomly arranged in a split-plot design with three replicates, where potassium rates were randomly distributed in the main plots and $\mathrm{Ca}$ sources were randomly arranged in the sub plots. The normal agricultural practices were carried out as commonly followed in El-Arish region.

\section{Data Recorded}

\section{Vegetative growth parameters}

Three plants from each replicate were randomly taken after 70 and 90 days from transplanting and the following data were recorded.

\section{Fresh weight/plant (g)}

Fresh weight of root, stem and leaves/ plant were determined as well as total fresh weight/plant was calculated.

\section{Dry weight/plant (g)}

Different plant parts of tomato plant sample were oven dried at $70^{\circ} \mathrm{C}$ until.

Constant weight and the dry weight of root, stem and leaves/plant were determined and total dry weight was calculated. 
Table (1): The physical and chemical properties of the experimental soil*

\begin{tabular}{c|cc}
\hline Property & $\begin{array}{c}\mathbf{1}^{\text {st }} \text { season } \\
\mathbf{( 2 0 1 3 - 1 4 )}\end{array}$ & $\begin{array}{c}\mathbf{2}^{\text {nd }} \text { season } \\
(\mathbf{2 0 1 4 - 1 5})\end{array}$ \\
\hline $\begin{array}{c}\text { Physical properties } \\
\text { Texture }\end{array}$ & Sandy Clay Loam & Sandy Clay Loam \\
Chemical properties & & \\
$\mathbf{p H}$ & 8.0 & 7.6 \\
EC (dSm $\left.{ }^{-\mathbf{1}}\right)$ & 0.7 & 1.3 \\
Total N (\%) & 0.03 & 0.10 \\
Total P (\%) & 0.26 & 0.30 \\
Total K (\%) & 0.62 & 0.50 \\
\hline
\end{tabular}

* Soil samples were taken from the $25 \mathrm{~cm}$ of the soil surface.

Table (2): The physical and chemical analyses of irrigation water.

\begin{tabular}{|c|c|c|c|c|c|c|c|c|c|}
\hline \multirow{3}{*}{$\begin{array}{c}\text { EC } \\
\text { Ppm }\end{array}$} & \multicolumn{9}{|c|}{ Soluble ions (meq. $\left.\mathrm{I}^{-1}\right)$} \\
\hline & \multicolumn{5}{|c|}{ Cations } & \multicolumn{4}{|c|}{ Anions } \\
\hline & $\mathbf{M g}^{-1}$ & $\mathbf{C a}^{++}$ & $\mathbf{M g}^{++}$ & $\mathrm{Na}^{+}$ & $\mathbf{K}^{+}$ & $\mathrm{Cl}^{-}$ & $\mathrm{HCO}_{3}^{-}$ & $\mathrm{CO}_{3}^{-}$ & $\mathrm{SO}_{4}^{-7}$ \\
\hline 3513 & 44.99 & 16.56 & 17.60 & 35.87 & 0.27 & 42.26 & 6.13 & - & 21.91 \\
\hline
\end{tabular}

\section{Yield and its components}

Fruits of all pickings tell the end of the experiment were counted and weighed and the following data were calculated:

a- Total marketable yield number and weight/plant.

b-Total unmarketable yield number and weight/plant.

\section{Statistical Analysis}

The obtained data were subjected to statistical analysis of variance according to Snedecor and Cochran (1980), and means separation was done according to Duncan's Multiple Range Test (1955).

\section{RESULTS AND DISCUSSION}

\section{Fresh Weight}

\section{Effect of potassium rates}

Results in Table 3 show that, in the first season, application of potassium had no significant effect on fresh weight of leaves, fresh weight of stem, and fresh weight of roots, except fresh weight of leaves at 70 DAT and total fresh weight at 70 and 90 DAT, where application of potassium at a rate of $80 \mathrm{~kg} \mathrm{~K} 2 \mathrm{O} / 540 \mathrm{~m}^{2}$ had a significant effect and recorded the highest value of total fresh weight/plant in both seasons. In the second season, there were significant effects for potassium soil application on all 
studied traits, except fresh weight of roots at 90 DAT which did not reach $5 \%$ level of probability. Application of $80 \mathrm{~kg} \mathrm{~K} 2 \mathrm{O} / 540$ $\mathrm{m}^{2}$ recorded the maximum values for all studied traits of plant fresh weight; viz., leaves, stem, roots, and total fresh weight of plant without significant difference with application of $60 \mathrm{~kg} \mathrm{~K} \mathrm{~K}_{2} \mathrm{O} / 540 \mathrm{~m}^{2}$ at 70 DAT on fresh weight of roots. These results are in agreement with those reported by Saida et al. (2014) and Ul-Hassan et al. (2016) who found that potassium nutrition significantly enhanced growth and biomass production of tomato plants. It could be concluded that soil application of $80 \mathrm{~kg}$ $\mathrm{K}_{2} \mathrm{O} / 540 \mathrm{~m}^{2}$ was the superior treatment for increasing fresh weight of tomato plant in the second season.

\section{Effect of calcium sources}

Results in Table 3 indicate that there were no significant differences among calcium foliar application treatments on fresh weight of tomato plant in the first season, and fresh weight of leaves as well as fresh weight of roots at 90 DAT in the second one. However, spraying tomato plant with Gurenkal $\left(5 \mathrm{ml} \mathrm{l}^{-1}\right)$ recorded the highest significant values of fresh weight of leaves, stem, roots as well as total fresh weight of plant at 70 and 90 DAT, followed by spraying with Ca-chelate $\left(5 \mathrm{~g}^{-1}\right)$ in the second season. Check treatment (without $\mathrm{Ca}$ ) recorded the lowest values of plant fresh weight in both seasons. These results are in harmony with the findings of Lopez and Satti (1996) and Lolaei (2012) who found that increasing $\mathrm{Ca}^{2+}$ concentration in leaves linearly increased total vegetative biomass. It was reported that increasing calcium rates caused positive gradual increase in tomato growth ( $R \mathbf{a d y}, \mathbf{2 0 1 2})$.

It could be said that spraying tomato plants with Gurenkal $\left(5 \mathrm{ml} \mathrm{l}^{-1}\right)$ as calcium source, followed by spraying with $\mathrm{Ca}$ chelate $\left(5 \mathrm{gl}^{-1}\right)$ were the superior treatments for enhancing plant fresh weight.
Effect of interaction between potassium and calcium

It is clear from the results in Table 4 that there were significant interaction effects between calcium and potassium on all studied tomato plant fresh weight traits in both seasons, except fresh weight of leaves at 70 DAT, fresh weight of roots at 70 and 90 DAT, total fresh weight at 90 DAT in the first season. However, application of 80 $\mathrm{kg} \mathrm{K}_{2} \mathrm{O} / 540 \mathrm{~m}^{2}+$ Gurenkal had the maximum value of fresh weight; viz., leaves, stem, and total fresh weight of plant after 70 or 90 DAT, with no significant differences with $80 \mathrm{~kg} \mathrm{~K} 2 \mathrm{O} / 540 \mathrm{~m}^{2}+\mathrm{Ca}$-chelateor without $\mathrm{Ca}$ in the first season, while in the second season application of $80 \mathrm{~kg} \mathrm{~K} 2 \mathrm{O} / 540 \mathrm{~m}^{2}+$ Gurenkal recorded the highest values of the pervious studied parameters.

It could be concluded that the best interaction treatments for increasing fresh weight of different parts of tomato plants was $80 \mathrm{~kg} \mathrm{~K}_{2} \mathrm{O} / 540 \mathrm{~m}^{2}+$ spraying with Gurenkal $\left(5 \mathrm{ml} \mathrm{l}^{-1}\right)$, followed by application of $80 \mathrm{~kg} \mathrm{~K} 2 \mathrm{O} / 540 \mathrm{~m}^{2}+$ Ca- chelate $\left(5 \mathrm{~g} \mathrm{l}^{-1}\right)$.

\section{Dry Weight}

\section{Effect of potassium rates}

Results in Table 5 illustrate significant effects for $\mathrm{K}_{2} \mathrm{O}$ on dry weight of tomato plants, except dry weight of stem in the first season and dry weight of root in the second one. The same results reveal that application of $\mathrm{K}_{2} \mathrm{O}$ at a rate of $80 \mathrm{~kg} \mathrm{~K}_{2} \mathrm{O} / 540 \mathrm{~m}^{2}$ was the superior treatment which increased dry weight of stem, root and total dry weight of plant in both seasons.

The increment in total dry weight of plant, especially in the second season may be attributed to the increments in dry weight of leaves, stem and roots. These results are in agreement with those reported by Wuzhong (2002), El-Nemr et al. (2012), Amjad et al. (2014) and UlHassan et al. (2016) who found a positive response to potassium concentration on dry weight of tomato plant. 
Table (3): Effect of potassium rates and calcium source on fresh weight of tomato plants (g) during 2013/2014 and 2014/2015 seasons.

\begin{tabular}{|c|c|c|c|c|c|c|c|c|c|c|c|c|c|c|c|c|}
\hline \multirow{4}{*}{$\begin{array}{l}\text { Parameter } \\
\text { Treatment }\end{array}$} & \multicolumn{16}{|c|}{ Fresh weight (g)/plant } \\
\hline & \multicolumn{2}{|c|}{ Leaves } & \multicolumn{2}{|r|}{ Stem } & \multicolumn{2}{|c|}{ Roots } & \multicolumn{2}{|c|}{ Total } & \multicolumn{2}{|c|}{ Leaves } & \multicolumn{2}{|c|}{ Stem } & \multicolumn{2}{|c|}{ Roots } & \multicolumn{2}{|c|}{ Total } \\
\hline & \multicolumn{16}{|c|}{ Days after transplanting } \\
\hline & 70 & 90 & 70 & 90 & 70 & 90 & 70 & 90 & 70 & 90 & 70 & 90 & 70 & 90 & 70 & 90 \\
\hline \multicolumn{17}{|c|}{ Effect of potassium rates } \\
\hline \multicolumn{3}{|c|}{$\overline{\left.\mathrm{K}_{2} \mathrm{O}(\mathrm{kg}) / 540 \mathrm{~m}^{2}\right)}$} & \multicolumn{6}{|c|}{ First season $(2013 / 2014)$} & \multicolumn{8}{|c|}{ Second season $(2014 / 2015)$} \\
\hline$\overline{40}$ & $299.0 \mathrm{~b}$ & $374.5 \mathrm{a}$ & $194.2 \mathrm{a}$ & $210.7 \mathrm{a}$ & $88.61 \mathrm{a}$ & $93.36 \mathrm{a}$ & $581.81 \mathrm{~b}$ & $678.56 \mathrm{c}$ & $293.7 \mathrm{c}$ & $341.4 \mathrm{c}$ & $142.7 \mathrm{c}$ & $177.2 \mathrm{c}$ & $96.2 \mathrm{~b}$ & $116.3 \mathrm{a}$ & $532.6 a$ & $620.1 \mathrm{c}$ \\
\hline 60 & $304.1 \mathrm{~b}$ & $386.7 \mathrm{a}$ & $186.7 \mathrm{a}$ & $224.3 \mathrm{a}$ & $89.17 \mathrm{a}$ & $92.43 \mathrm{a}$ & $579.97 \mathrm{~b}$ & $703.43 \mathrm{~b}$ & $356.7 \mathrm{~b}$ & $382.0 \mathrm{~b}$ & $163.7 \mathrm{~b}$ & $207.9 \mathrm{~b}$ & $112.8 \mathrm{ab}$ & $118.9 \mathrm{a}$ & $633.2 \mathrm{a}$ & $708.7 b$ \\
\hline 80 & $335.1 \mathrm{a}$ & $392.0 \mathrm{a}$ & $202.4 \mathrm{a}$ & $251.9 \mathrm{a}$ & $90.50 \mathrm{a}$ & $92.65 \mathrm{a}$ & $628.00 \mathrm{a}$ & $736.55 \mathrm{a}$ & $422.7 \mathrm{a}$ & $425.6 \mathrm{a}$ & $194.4 \mathrm{a}$ & $234.7 \mathrm{a}$ & $120.0 \mathrm{a}$ & $129.8 \mathrm{a}$ & $740.4 \mathrm{a}$ & $790.1 \mathrm{a}$ \\
\hline \multicolumn{17}{|c|}{ Effect of calcium source } \\
\hline Without Ca & $314.6 \mathrm{a}$ & $385.2 \mathrm{a}$ & $189.3 \mathrm{a}$ & $225.7 \mathrm{a}$ & $88.59 \mathrm{a}$ & $91.00 \mathrm{a}$ & $592.5 \mathrm{a}$ & $701.9 \mathrm{a}$ & $323.6 \mathrm{~b}$ & $377.7 \mathrm{a}$ & $152.7 \mathrm{~b}$ & $198.4 \mathrm{~b}$ & $94.3 \mathrm{~b}$ & $124.5 \mathrm{a}$ & $570.6 \mathrm{a}$ & $690.4 b$ \\
\hline Ca-chelate* & $332.2 \mathrm{a}$ & $381.5 \mathrm{a}$ & $199.3 \mathrm{a}$ & $226.5 \mathrm{a}$ & $89.77 \mathrm{a}$ & $93.83 \mathrm{a}$ & $621.2 \mathrm{a}$ & $701.8 \mathrm{a}$ & $370.1 \mathrm{a}$ & $371.8 \mathrm{a}$ & $171.4 \mathrm{a}$ & $202.9 \mathrm{~b}$ & $115.6 \mathrm{a}$ & $119.8 \mathrm{a}$ & $661.9 \mathrm{a}$ & $694.5 b$ \\
\hline Gurenkal* & $311.5 \mathrm{a}$ & $386.5 \mathrm{a}$ & $194.7 \mathrm{a}$ & $234.8 \mathrm{a}$ & $89.93 \mathrm{a}$ & $93.6 \mathrm{a}$ & $596.1 \mathrm{a}$ & $714.9 \mathrm{a}$ & $379.4 \mathrm{a}$ & $399.4 \mathrm{a}$ & $176.6 \mathrm{a}$ & $218.4 \mathrm{a}$ & $118.9 \mathrm{a}$ & $120.7 \mathrm{a}$ & $637.7 \mathrm{a}$ & $734.0 \mathrm{a}$ \\
\hline
\end{tabular}

Values having the same alphabetical letter(s) did not significantly differ at 0.05 level of significance according to Duncan's multiple range test.

*Ca-chelate and Gurenkal were used at a rate of $5 \mathrm{~g}^{-1}$ and $5 \mathrm{ml} \mathrm{l}^{-1}$, respectively. 
Table (4): Effect of interaction between potassium rates and calcium source on fresh weight of tomato plants during 2013/2014 and 2014/2015 seasons.

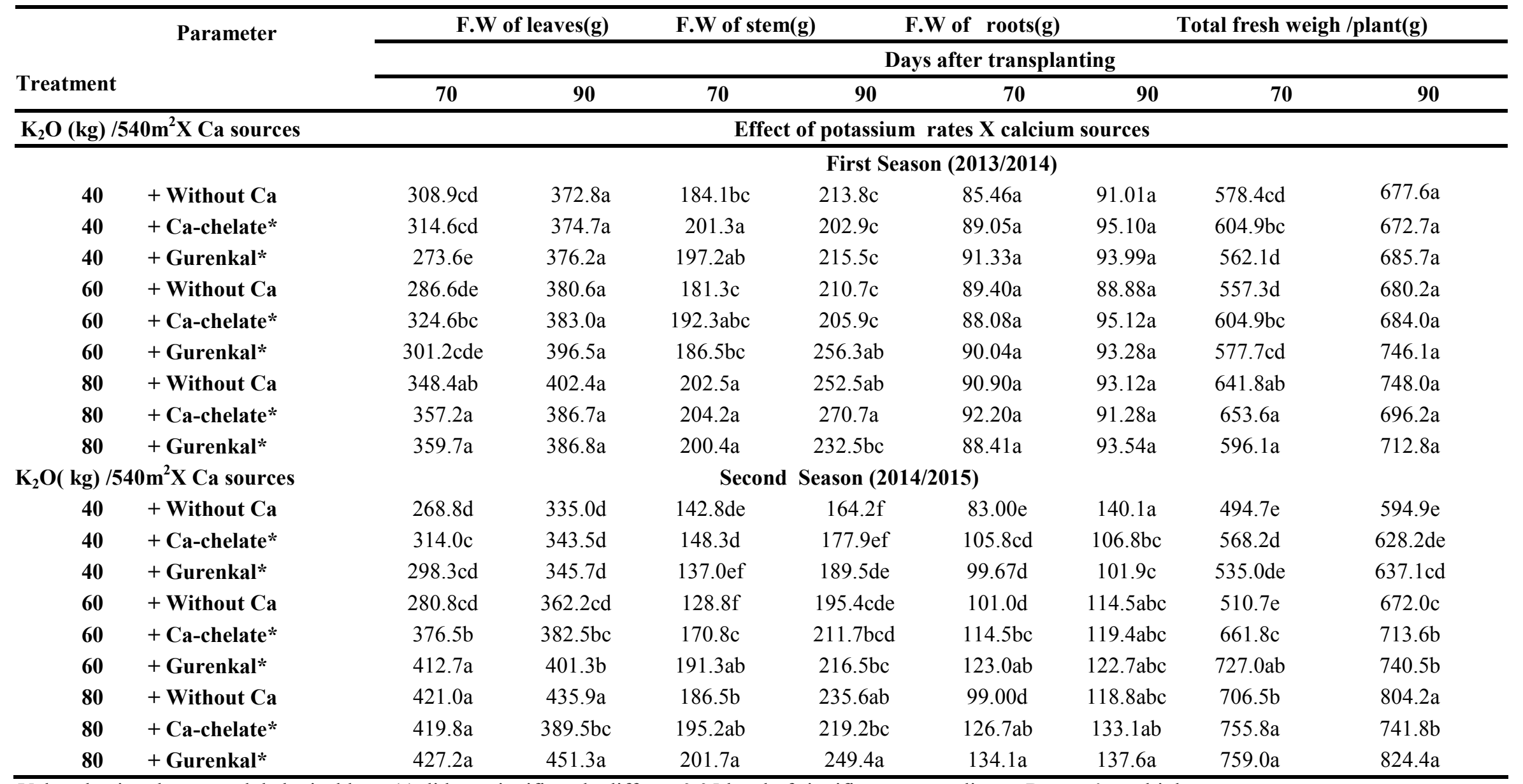


Table (5): Effect of potassium rates and calcium source on dry weight of tomato plants during 2013/2014 and $2014 / 2015$ seasons.

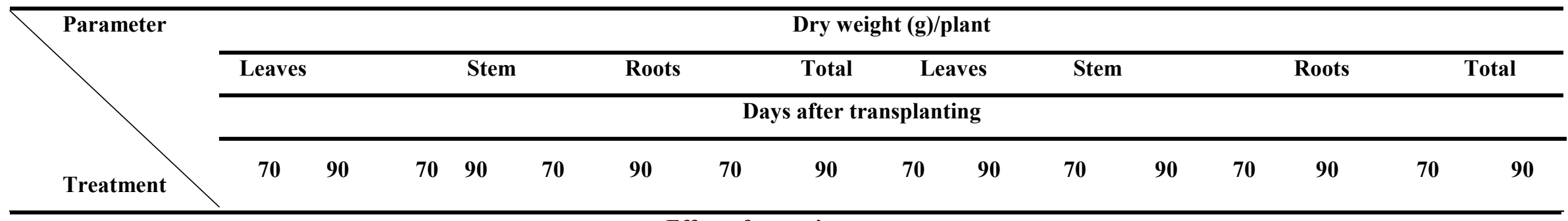

Effect of potassium rates

First season (2013/2014)

Second season $(2014 / 2015)$

$\mathrm{K}_{2} \mathrm{O}(\mathrm{kg}) / 540 \mathrm{~m}^{2}$

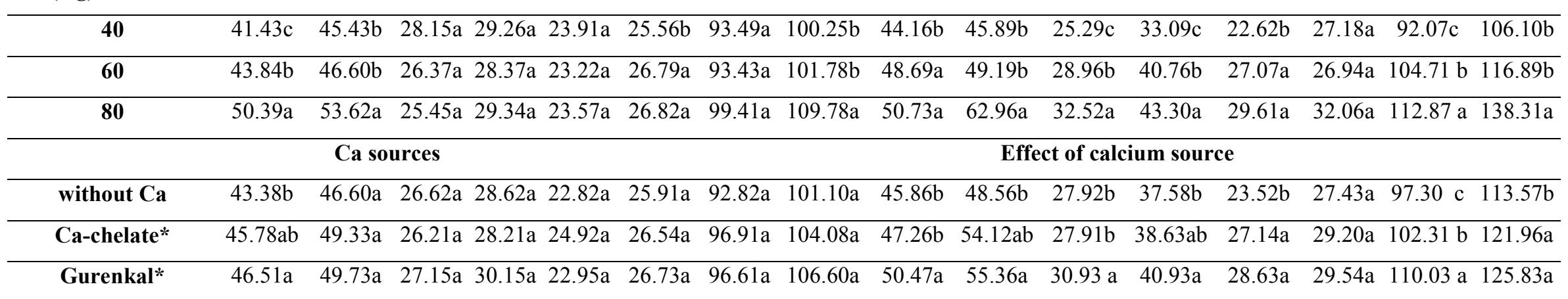

Values having the same alphabetical letter(s) did not significantly differ at 0.05 level of significance according to Duncan's multiple range test.

*Ca-chelate and Gurenkal were used at a rate of $5 \mathrm{~g} \mathrm{l}^{-1}$ and $5 \mathrm{ml} \mathrm{l}^{-1}$, respectively. 


\section{Effect of calcium sources}

Results in Table 5 show insignificant effects due to application of calcium on all dry weight traits in the first season expressed in dry weight of roots, stem, leaves and consequently total dry weight of plant at both studied sampling dates, except dry weight of leaves after 70 DAT, while in the second season application of Gurenkal gave the maximum values of the studied parameters, followed by Ca- chelate.

The increments in total dry weight at 70 and 90 DAT may be owe to the increase in dry weight of different plant parts (roots, stem, leaves). These results are in a good line with those reported by Hao and Papadopoulos (2004), and Kazemi(2013).

\section{Effect of interaction between potassium and calcium}

It is clear from the results in Table 6 that the interaction among potassium and calcium treatments had significant effects on all studied parameters, except dry weight of stem at 70 and 90 DAT and dry weight of roots at 70 DAT in the first season. The interaction between application of $80 \mathrm{~kg}$ $\mathrm{K}_{2} \mathrm{O} / 540 \mathrm{~m}^{2}$ and all sources of $\mathrm{Ca}$ (Gurenkal; Ca-chelate; without Ca) increased dry weight of leaves at 70 and 90 DAT and dry weight of roots at 90 DAT that led to increase in total dry weight of plant at 70 and 90 DAT in the first season.

In the second season, the interaction between application of $80 \mathrm{~kg} \mathrm{~K} 2 \mathrm{O} / 540 \mathrm{~m}^{2}$ + Gurenkal was the best interaction treatment which led to increase the dry weight of leaves at 70 and 90 DAT and dry weight of stem at 70 DAT as well as dry weight of roots at 90 DAT. The increase in these parameters led to increase in total dry weight of tomato plant.

\section{Yield and Its Components}

\section{Marketable and unmarketable yield}

\section{Effect of potassium rates}

Results in Table 7 reveal that application of potassium had significant effects on total marketable yield/plant, total yield $/ 540 \mathrm{~m}^{2}$ in both seasons, and fruit weight of unmarketable yield in the first season, but it did not reflect any significant effects on number of unmarketable fruits in both seasons. Application of $80 \mathrm{~kg} \mathrm{~K} 2 \mathrm{O} / 540 \mathrm{~m}^{2}$ was the best treatment for increasing the previous studied yield parameters.

The increment in total yield may be owe to the increment in total yield of plant expressed in fruits number and the other yield components. The increase in plant yield may be due to the increases in photosynthetic pigments due to application of $\mathrm{K}_{2} \mathrm{O}$ which led to increase in photo assimilation expressed in fresh and dry weight of different parts of tomato plants and consequently increase in yield per plant and per a single greenhouse $\left(540 \mathrm{~m}^{2}\right)$.

It could be concluded that both total yield per greenhouse and unmarketable fruit weight had the highest values with application of80 $\mathrm{kg} \mathrm{K} \mathrm{K}_{2} \mathrm{O} / 540 \mathrm{~m}^{2}$ as soil application.

\section{Effect of calcium sources}

Results in Table (7) illustrate the effect of Ca sources on total marketable yield and unmarketable yield /a single greenhouse $\left(540 \mathrm{~m}^{2}\right)$. The same results show that application of $\mathrm{Ca}$ in different sources had no significant effect on the previous parameters in the second season and on fruit weight of unmarketable yield in the first season. Application of $\mathrm{Ca}$ as Gurenkal at concentration of $5 \mathrm{ml} \mathrm{l}^{-1}$ as foliar spray increased the components of total yield/plant (numbers and weight of fruits) which led to an increase in total yield/a greenhouse in the first season. 
Table (6): Effect of interaction between potassium rates and calcium sources on dry weight of tomato plants during $2013 / 2014$ and $\mathbf{2 0 1 4 / 2 0 1 5}$ seasons.

\begin{tabular}{|c|c|c|c|c|c|c|c|c|c|}
\hline \multirow{3}{*}{ Treatment } & \multirow{3}{*}{ Parameter } & D.W of 1 & $\operatorname{ves}(\mathrm{g})$ & D.W of stem(g) & & D.W of 1 & & Total Dry & $\operatorname{eigh}(g)$ \\
\hline & & \multicolumn{8}{|c|}{$\begin{array}{r}\text { Days after transplanting } \\
\end{array}$} \\
\hline & & 70 & 90 & $\mathbf{7 0}$ & 90 & $\mathbf{7 0}$ & 90 & 70 & 90 \\
\hline \multicolumn{10}{|c|}{ Effect of potassium rates $X$ calcium sources } \\
\hline \multicolumn{4}{|c|}{$\mathrm{K}_{2} \mathrm{O}(\mathrm{kg}) / 540 \mathrm{~m}^{2} \mathrm{X}$ Ca sources } & \multicolumn{4}{|c|}{ First season $(2013 / 2014)$} & & \\
\hline 40 & + without Ca & $41.75 \mathrm{c}$ & $45.08 \mathrm{~cd}$ & $27.99 \mathrm{a}$ & $29.32 \mathrm{a}$ & $23.11 \mathrm{a}$ & $26.45 \mathrm{ab}$ & $92.85 \mathrm{bc}$ & 100.9def \\
\hline 40 & + Ca-chelate* & $41.26 \mathrm{c}$ & $45.93 \mathrm{~cd}$ & $27.37 \mathrm{a}$ & $28.37 \mathrm{a}$ & $25.42 \mathrm{a}$ & $24.21 \mathrm{c}$ & $94.05 \mathrm{bc}$ & $98.51 \mathrm{ef}$ \\
\hline 40 & + Gurenkal* & $41.29 c$ & $45.29 \mathrm{~cd}$ & $29.09 a$ & $30.09 a$ & $23.20 \mathrm{a}$ & $26.00 \mathrm{abc}$ & $93.58 \mathrm{bc}$ & $101.4 c-f$ \\
\hline 60 & + without Ca & $40.76 \mathrm{c}$ & $43.09 \mathrm{~d}$ & $25.46 a$ & $26.12 \mathrm{a}$ & $23.14 \mathrm{a}$ & $25.23 b c$ & $89.36 \mathrm{c}$ & $94.45 \mathrm{f}$ \\
\hline 60 & + Ca-chelate* & $45.12 b$ & $48.45 \mathrm{bc}$ & $25.91 \mathrm{a}$ & $27.91 \mathrm{a}$ & $25.00 \mathrm{a}$ & $27.63 \mathrm{a}$ & $96.03 \mathrm{ab}$ & 104.0b-e \\
\hline 60 & + Gurenkal* & $45.63 b$ & $48.30 \mathrm{bc}$ & $27.75 a$ & $31.08 \mathrm{a}$ & $21.52 \mathrm{a}$ & $27.52 \mathrm{a}$ & $94.90 \mathrm{abc}$ & $106.9 a-d$ \\
\hline 80 & + without Ca & $47.63 b$ & $51.63 \mathrm{ab}$ & $26.41 \mathrm{a}$ & $30.41 \mathrm{a}$ & $22.22 \mathrm{a}$ & $26.04 \mathrm{abc}$ & $96.26 \mathrm{ab}$ & $108.1 \mathrm{abc}$ \\
\hline 80 & + Ca-chelate* & $50.96 a$ & $53.62 \mathrm{a}$ & $25.34 a$ & $28.34 \mathrm{a}$ & $24.34 \mathrm{a}$ & $27.77 \mathrm{a}$ & $100.6 \mathrm{a}$ & $109.7 \mathrm{ab}$ \\
\hline 80 & + Gurenkal* & $52.60 \mathrm{a}$ & $55.60 \mathrm{a}$ & $24.61 \mathrm{a}$ & $29.28 \mathrm{a}$ & $24.14 \mathrm{a}$ & $26.66 \mathrm{ab}$ & $101.3 \mathrm{a}$ & $111.5 \mathrm{a}$ \\
\hline \multicolumn{2}{|c|}{$\mathrm{K}_{2} \mathrm{O}(\mathrm{kg}) / 540 \mathrm{~m}^{2} \mathrm{X}$ Ca sources } & \multicolumn{8}{|c|}{ Second season $(2014 / 2015)$} \\
\hline $\mathbf{4 0}$ & + without Ca & $43.04 \mathrm{f}$ & $46.20 \mathrm{~cd}$ & $25.70 \mathrm{~d}$ & $30.07 \mathrm{f}$ & $19.73 \mathrm{f}$ & $30.10 \mathrm{bc}$ & $88.47 \mathrm{f}$ & $106.4 d$ \\
\hline 40 & + Ca-chelate* & $43.80 \mathrm{ef}$ & $47.20 \mathrm{~cd}$ & $25.30 \mathrm{~d}$ & $32.93 \mathrm{ef}$ & $24.27 \mathrm{e}$ & $26.03 c$ & $93.37 \mathrm{e}$ & $106.2 d$ \\
\hline 40 & + Gurenkal* & $45.63 \mathrm{de}$ & $44.27 \mathrm{~d}$ & $24.87 \mathrm{~d}$ & $36.27 \mathrm{~d}$ & $23.87 \mathrm{e}$ & $25.40 \mathrm{c}$ & $94.37 \mathrm{e}$ & $105.9 \mathrm{~d}$ \\
\hline 60 & + without Ca & $45.23 \mathrm{ef}$ & $48.00 \mathrm{~cd}$ & $25.23 \mathrm{~d}$ & $35.47 \mathrm{de}$ & $22.43 \mathrm{e}$ & $26.30 \mathrm{c}$ & $92.90 \mathrm{e}$ & $109.8 \mathrm{~d}$ \\
\hline 60 & + Ca-chelate* & $50.10 \mathrm{bc}$ & $51.50 \mathrm{c}$ & $31.70 \mathrm{bc}$ & $43.17 \mathrm{~b}$ & $26.27 \mathrm{~d}$ & $28.40 \mathrm{bc}$ & $108.1 \mathrm{~cd}$ & $123.1 \mathrm{c}$ \\
\hline 60 & + Gurenkal* & $50.73 b$ & $48.07 \mathrm{~cd}$ & $29.93 c$ & $43.63 \mathrm{~b}$ & $32.50 \mathrm{a}$ & $26.13 c$ & $113.2 \mathrm{~b}$ & $117.8 \mathrm{c}$ \\
\hline 80 & + without Ca & $49.30 \mathrm{bc}$ & $51.47 \mathrm{c}$ & $32.83 \mathrm{~b}$ & $47.20 \mathrm{a}$ & $28.40 \mathrm{c}$ & $25.90 \mathrm{c}$ & $110.5 \mathrm{bc}$ & $124.6 \mathrm{c}$ \\
\hline 80 & + Ca-chelate* & $47.87 \mathrm{~cd}$ & $63.67 \mathrm{~b}$ & $26.73 d$ & $39.80 \mathrm{c}$ & $30.90 \mathrm{ab}$ & $33.17 \mathrm{ab}$ & $105.5 d$ & $136.6 \mathrm{~b}$ \\
\hline 80 & + Gurenkal* & $55.03 \mathrm{a}$ & $73.73 a$ & $38.00 \mathrm{a}$ & $42.90 \mathrm{~b}$ & $29.53 b c$ & $37.10 \mathrm{a}$ & $122.6 \mathrm{a}$ & $153.7 \mathrm{a}$ \\
\hline
\end{tabular}

Values having the same alphabetical letter(s) did not significantly differ at 0.05 level of significance according to Duncan's multiple range test.

*Ca-chelate and Gurenkal were used at a rate of $5 \mathrm{~g} \mathrm{I}^{-1}$ and $5 \mathrm{ml} \mathrm{l}^{-1}$, respectively. 
Our results are in agreement with those of other researcher where many efforts owed the increment in yield and its components due to foliar application of calcium to the vital role of calcium as one of the essential macroelements necessary for plant growth. It is used for maintenance of the plant cell structure and increasing resistance to environmental stresses (salinity, drought, chilling, heat, ... etc.) (Mestre et al., 2012).

It is also appear to play an essential role in the inhibition of abscission and delays leaf senescence, plays a compratively role in enzyme activation (Mengel and Kirkby, 1978); and stimulatethe accumulation of phytoalexin, which implicated in the defense mechanisms of plants against fungal attacks (Zook et al., 1987; Aghofack- Nguemeziet al., 2014) and consequantly led to an increase in chloroohyll content, laef area / plant, photo-assimilation and plant growth. The increment in plant growth reflected positively on increasing number of flowers/cluster, number of fruits/cluster, number of fruits/plant, fruits weight and this in turn increase yield/ha. (AghofackNguemezi and Tatchago, 2010; Mestre et al., 2012; Elbeik, 2014; Ilyas et al., 2014). On the other hand, Rab and Haq (2012) found that there were no significant differences between control and foliar application of $\mathrm{CaCl}_{2}$ on tomato fruit weight, and yield/fed.

It could be concluded that application of $\mathrm{Ca}$ as Gurenkal increased fruits number and weight of marketable yield/plant and increased total yield per a single greenhouse $\left(540 \mathrm{~m}^{2}\right)$.

\section{Effect of interaction between potassium and calcium}

Results in Table 8 indicate that there were significant effects for the interaction between $\mathrm{Ca}$ and $\mathrm{K}$ on all studied traits in both seasons, except unmarketable fruits weight/plant in the first season. The same results show that the interaction between application of $80 \mathrm{~kg} \mathrm{~K} \mathrm{~K}_{2} \mathrm{O} / 540 \mathrm{~m}^{2}+$ Gurenkal (as a source of $\mathrm{Ca}$ ) was the best interaction treatment for increasing total yield/plant and reducing unmarketable yield/plant leading to an increment in yield/greenhouse in both seasons. The increment in total marketable yield/plant may be owe to decreasing unmarketable yield and the effect of $\mathrm{K}$ and $\mathrm{Ca}$ on photosynthetic pigments which increased the photo-assimilation process and increase in fresh and dry weight of different parts of tomato plant (Tables 4 and 5).

It could be concluded that the best interaction treatment for increasing total marketable yield/plant and per greenhouse as well as decreasing unmarketable yield of tomato plants was application of $80 \mathrm{~kg}$ $\mathrm{K}_{2} \mathrm{O} / 540 \mathrm{~m}^{2}+$ Gurenkal as a source of $\mathrm{Ca}$ foliar application.

\section{REFERENCES}

Adams, P. and El-Gizawy, A.M. (1988). Effect of calcium stress on the calcium status of tomatoes grown in NFT. Act. Hort., 222: 15-22.

Afzal, I.; Munir, F.; Ayub, C.M.; Basra, S.M.A.; Hameed, A. and Shah, F. (2013). Ethanol priming: an effective approach to enhance germination and seedling development by improving antioxidant system in tomato seeds. Acta Sci. Pol., Hortorum Cultus, 12: 129-137.

Aghofack-Nguemezi, J. and Tatchago, V. (2010). Effect of fertilization calcium and/or magnesium on the growth, development of plant and the quality of tomato fruits in the Western Highlands of Cameroon., J. Agric. Res., 5(10): 821831.

Aghofack-Nguemezi, J.; Noumbo, G.T. and Nkumbe, C.N. (2014). Influence of calcium and magnesium based fertilizers on fungal diseases, plant growth parameters and fruit quality of three varieties of tomato (Solanum lycopersicum). J. Sci. Technol., 34 (1): 9-20. 
Table (7): Effect of potassium rates and calcium sources on total yield of tomato plants during 2013/2014 and 2014/2015 seasons.

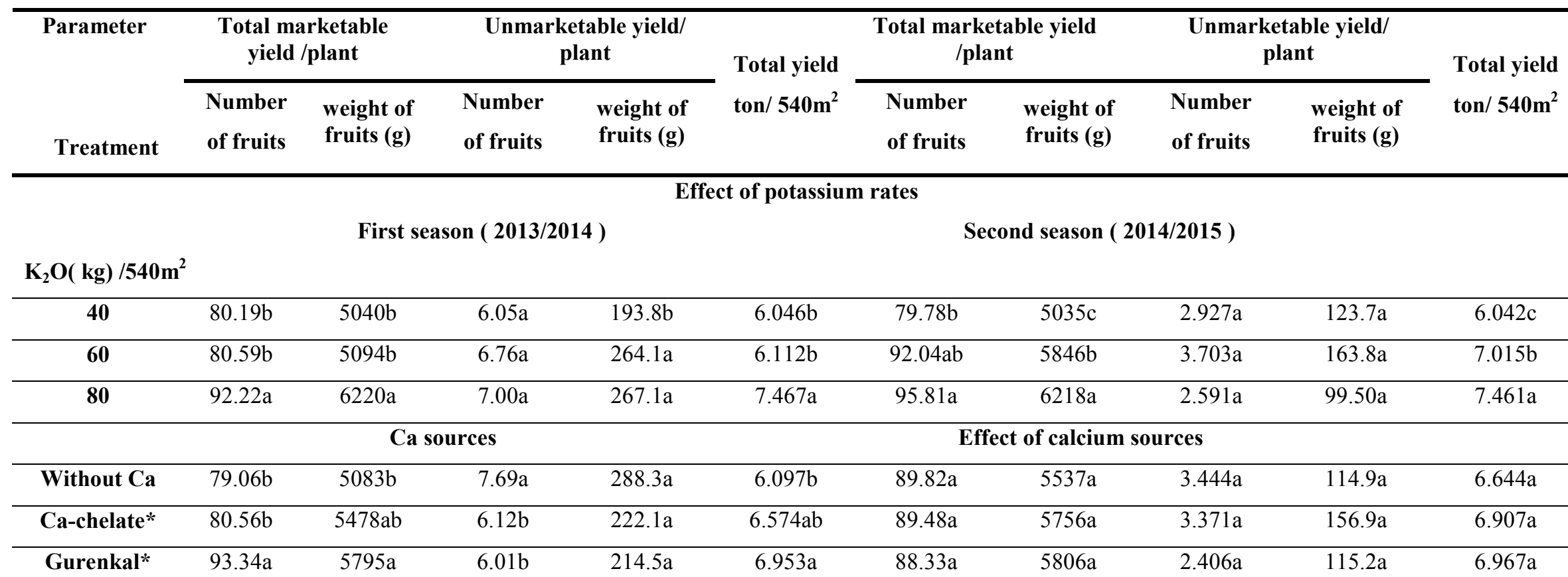

Values having the same alphabetical letter(s) did not significantly differ at 0.05 level of significance according to Duncan's multiple range test.

*Ca-chelate and Gurenkal were used at a rate of $5 \mathrm{~g} \mathrm{I}^{-1}$ and $5 \mathrm{ml} \mathrm{l}^{-1}$, respectively. 
Table (8): Effect of interaction between potassium rates and calcium sources on total yield of tomato plants during $2013 / 2014$ and 2014/2015 seasons.

\begin{tabular}{|c|c|c|c|c|c|c|c|c|c|c|c|}
\hline \multirow{2}{*}{\multicolumn{2}{|c|}{ Parameter }} & \multicolumn{2}{|c|}{$\begin{array}{c}\text { Total marketable yield } \\
\text { /plant }\end{array}$} & \multicolumn{2}{|c|}{$\begin{array}{c}\text { Unmarketable yield } \\
\text { /plant }\end{array}$} & \multirow{2}{*}{$\begin{array}{l}\text { Total yield } \\
\text { ton } / 540 \mathrm{~m}^{2}\end{array}$} & \multicolumn{2}{|c|}{$\begin{array}{c}\text { Total marketable } \\
\text { yield /plant }\end{array}$} & \multicolumn{2}{|c|}{$\begin{array}{c}\text { Unmarketable yield } \\
\text { /plant }\end{array}$} & \multirow[b]{2}{*}{$\begin{array}{l}\text { Total yield } \\
\text { ton } / 540 \mathrm{~m}^{2}\end{array}$} \\
\hline & & $\begin{array}{l}\text { Number } \\
\text { of fruits }\end{array}$ & $\begin{array}{l}\text { weight of } \\
\text { fruits (g) }\end{array}$ & $\begin{array}{l}\text { Number } \\
\text { of fruits }\end{array}$ & $\begin{array}{l}\text { weight of } \\
\text { fruits (g) }\end{array}$ & & $\begin{array}{l}\text { Number } \\
\text { of fruits }\end{array}$ & $\begin{array}{l}\text { weight of } \\
\text { fruits }(g)\end{array}$ & $\begin{array}{l}\text { Number } \\
\text { of fruits }\end{array}$ & $\begin{array}{c}\text { weight } \\
\text { of fruits (g) }\end{array}$ & \\
\hline & & \multicolumn{10}{|c|}{ Effect of potassium rates $X$ Calcium sources } \\
\hline \multicolumn{2}{|c|}{$\begin{array}{l}\mathrm{K}_{2} \mathrm{O}(\mathrm{kg}) / 540 \mathrm{~m}^{2} \mathrm{X} \mathrm{Ca} \\
\text { sources }\end{array}$} & \multicolumn{5}{|c|}{ First season $(2013 / 2014)$} & \multicolumn{5}{|c|}{ Second season $(2014 / 2015)$} \\
\hline 40 & + without Ca & $78.62 d$ & $4915 \mathrm{ef}$ & $7.38 \mathrm{ab}$ & $223.2 \mathrm{a}$ & $5.8928 \mathrm{ef}$ & $76.22 \mathrm{c}$ & $4918 \mathrm{e}$ & $3.557 \mathrm{abc}$ & $126.3 b$ & $5.901 \mathrm{e}$ \\
\hline 40 & + Ca-chelate* & $73.33 \mathrm{~d}$ & $5155 \mathrm{e}$ & $5.65 \mathrm{de}$ & $207.5 \mathrm{a}$ & $6.1872 \mathrm{de}$ & $86.11 \mathrm{bc}$ & 5274de & $2.447 \mathrm{c}$ & $132.1 \mathrm{~b}$ & $6.329 \mathrm{de}$ \\
\hline 40 & + Gurenkal* & $88.45 b c$ & $5049 \mathrm{e}$ & $5.12 \mathrm{e}$ & $150.6 \mathrm{a}$ & $6.0592 \mathrm{e}$ & $77.00 \mathrm{c}$ & $4913 \mathrm{e}$ & $2.777 \mathrm{bc}$ & $112.7 \mathrm{~b}$ & $5.896 \mathrm{e}$ \\
\hline 60 & + without Ca & $76.81 \mathrm{~d}$ & $4584 f$ & $8.18 \mathrm{a}$ & $342.1 \mathrm{a}$ & $5.4992 \mathrm{f}$ & $91.11 \mathrm{ab}$ & $5650 \mathrm{~cd}$ & $4.110 \mathrm{ab}$ & $109.0 \mathrm{~b}$ & $6.780 \mathrm{~cd}$ \\
\hline 60 & + Ca-chelate* & $76.58 \mathrm{~d}$ & $5104 \mathrm{e}$ & 5.76de & $214.5 \mathrm{a}$ & $6.1232 \mathrm{e}$ & $90.00 \mathrm{ab}$ & $5819 b c$ & $4.780 \mathrm{a}$ & $236.3 \mathrm{a}$ & $6.983 b c$ \\
\hline 60 & + Gurenkal* & $88.40 \mathrm{bc}$ & $5596 \mathrm{~d}$ & $6.33 \mathrm{~cd}$ & $235.7 \mathrm{a}$ & $6.7152 \mathrm{~cd}$ & $95.00 \mathrm{ab}$ & $6069 \mathrm{abc}$ & $2.220 \mathrm{c}$ & $145.9 b$ & $7.283 \mathrm{abc}$ \\
\hline 80 & + without Ca & $81.71 \mathrm{~cd}$ & $5748 \mathrm{c}$ & $7.50 \mathrm{ab}$ & $299.7 \mathrm{a}$ & $6.9008 \mathrm{bc}$ & $102.1 \mathrm{a}$ & $6043 \mathrm{abc}$ & $2.667 \mathrm{bc}$ & $109.3 b$ & $7.251 \mathrm{abc}$ \\
\hline 80 & + Ca-chelate* & $91.76 \mathrm{~b}$ & $6176 b$ & $6.93 \mathrm{bc}$ & $244.4 \mathrm{a}$ & $7.4128 b$ & $92.33 \mathrm{ab}$ & $6174 \mathrm{ab}$ & $2.887 \mathrm{bc}$ & $102.2 \mathrm{~b}$ & $7.409 \mathrm{ab}$ \\
\hline 80 & + Gurenkal* & $103.18 \mathrm{a}$ & $6737 a$ & $6.58 \mathrm{bcd}$ & $257.3 a$ & $8.0848 \mathrm{a}$ & $93.00 \mathrm{ab}$ & $6436 \mathrm{a}$ & $2.220 \mathrm{c}$ & $86.94 b$ & $7.723 a$ \\
\hline
\end{tabular}

Values having the same alphabetical letter(s) did not significantly differ at 0.05 level of significance according to Duncan's multiple range test.

*Ca-chelate and Gurenkal were used at a rate of $5 \mathrm{~g}^{-1}$ and $5 \mathrm{ml} \mathrm{l}^{-1}$, respectively. 
Amjad, M.; Akhtar, J.; Anwar, M.; Imran, S.h.; and Jacobsen, S. (2014). Soil and foliar application of potassium enhances fruit yield and quality of tomato under salinity. Turk. J. Biol., 38: 208-218.

Bidariand, B.I. and Hebsur, N.S. (2011). Potassium in relation to yield and quality of selected vegetable crops, Karnataka J. Agric. Sci., 24(1):55-59.

Cakmak, I. (2005). The role of potassium in alleviating detrimental effects of abiotic stresses in plants. J. Plant Nutrition. Soil Sci., 168: 521-530.

Chapagain, B.P. and Wiesman, Z. (2004). Effect of potassium magnesium chloride in the fertigation solution as partial source of potassium on growth, yield and quality of greenhouse tomato. Sci. Hort., 99:279-288.

Dorais, M.; Papadopoulos, A.P. and Gosselin, A. (2001). Greenhouse tomato fruit quality. Hort. Rev. Amer. Soc. Hort. Sci., 26: 239-319.

Duncan, D.B. (1955). Multiple Range and Multiple F-test. Biometrics, 11: 1-42.

Elbeik, A.K.M. (2014). Effect of calcium spray on growth, yield, blossom-end rot occurrence and storability of tomatoes under calcareous soil conditions in delta of El-Arish Valley. Zagazig J. Agric. Res., 41 (2): 257-271.

El-Nemr, M.A.; Abd El-Baky, M.M.H.; Salman, S.R. and El-Tohamy, W.A. (2012). Effect of different potassium levels on the growth, yield and quality of tomato grown in sand-ponic culture. Australian J. Basic and Appl. Sci., 6(3): 779-784.

Friedman, H; Goldsmidt, E.E. and Halevy, A.H. (1989). Involvement of Calcium in the Photoperiodic flower induction process of Pharbitis nil. Plant Physiol., 89: 530-534.
Garcia, J.M.; Ballesteros, J.M. and Albi, M.A. (1995). Effect of foliar application of $\mathrm{CaCl} 2$ on tomato stored at different temperatures. J. Agric. Food chem., 43: 9-12.

Hao, X. and Papadopoulos, A.P. (2004). Effect of calcium and magnesium on plant growth, biomass partitioning, and fruit yield of winter greenhouse tomato. Hort. Sci., 39(3): 512-515.

Hao, X.; Papadopoulos, A.P.; Dorais, M.; Ehret, D.L.; Turcotte, G. and Gosselin, A. (2000). Improving tomato fruit quality by raising the EC of NFT nutrient solution and calcium spraing: effect of growth, photosynthesis, yield and quality. Acta. Hort. 511: 213-221.

Ho, L.C.; Hand, D.J. and Fussell, M. (1999). Improvement of tomato fruit quality by calcium nutrition. Acta. Hort., 481: 463-468.

Holder, R. and Cockshull, K.E. (1990). Effect of humidity on the growth and yield of glasshouse tomatoes. J. Hort. Sci. 65: 31-39.

Ilyas, M.; Ayub, G.; Hussain, Z.; Ahmad, M.; Bibi, B.; Rashid, A. and Luqman, M. (2014). Response of tomato to different levels of calcium and magnesium concentration. World Appl. Sci. J., 31(9): 1560-1564.

Jensen, C.R.; Battilani, A.; Plauborg, F.; Psarras, G.; Chartzoulakis, K.; Janowiak, F.; Stikic, R.; Jovanovic, Z.; Li, G. and Qi, X. (2010). Deficit irrigation based on drought tolerance and root signaling in potatoes and tomatoes. Agric. Water Manage. 98: 403-413.

Kadir, S.A. (2004). Fruit quality at harvest of 'Jonathan' apple treated with foliar applied calcium chloride. J. Plant Nutrition, 27: 1991-2006.

Kazemi, M. (2013). Vegetative and reproductive growth of tomato plants affected by calcium and humic acid. Bull. Environ. Pharmacol. Life Sci., (11): 24-29. 
Lester, G.E.; Jifon, J.L. and Rogers, G. (2005). Impact of potassium nutrition on food quality of fruits and vegetable. J. Ame. Soc. Hort. Sci., 130(1): 649- 653.

Lolaei, A. (2012). Effect of calcium chloride on growth and yield of tomato under sodium chloride stress. J. Ornamental Hort. Plants, 2(3): 155-160.

Lopez, M.V. and Satti, S.M.E. (1996). Calcium and potassium-enhanced growth and yield of tomato under sodium chloride stress. Plant Sci., 114: 19-27.

Mengel, K. and Kirkby, E. (1978). Principles of Plant Nutrition. $1^{\text {st }}$ Ed., Int. Potash Inst., Worblaufen-Bern, Switzerland.

Mestre, T.C.; Garcia-Sanchez, F.; Rubio, F.; Martinez, V. and Rivero, R.M. (2012). Glutathione homeostasis as an important and novel factor controlling blossom-end rot development in calcium-deficient tomato fruits. J. Plant Physiol., 169: 1719-1727.

Rab, A. and Haq, I. (2012). Foliar application of calcium chloride and borax influences plant growth, yield, and quality of tomato (Lycopersicon esculentum Mill.) fruit. Turk J. Agric., 36: 695-701.

Rady, M.M. (2012). A novel organomineral fertilizer can mitigate salinity stress effects for tomato production on reclaimed saline soil. South Afr. J. Bot., 81: 8-14.

Saida, C.; Houria, B.; Mébarek, B. (2014). Interactive effects of salinity and potassium on physio-morphological traits of tomato (Lycopersicon esculentum Mill.; var: heintz). Agric. Biol. J. N. Ame., 5 (3): 135-143.

Savic, S.; Liu, F.; Stikic, R.; Jacobsen, S.E.; Jensen, C.R. and Jovanovic, Z. (2009). Comparative effects of partial root zone drying and deficit irrigation on growth and physiology of tomato plants. Arch Biol. Sci. Belgrade, 61: 801-810.

Simon, E.W. (1978). The symptoms of calcium deficiency in phosphide as an alternative to methyl bromide in tomato crops. Scientia Hort., 150: 54-58.

Snedecor, G.W. and Cochran, W.G. (1980). Statistical Methods $7^{\text {th }}$ Ed. Iowa State Univ. Press. Ames. Iowa, USA.

Ul-Hassan, Z.; Kubar, K.A.; Chhajro, M.A.; Kandhro, M.N.; Jamro, G.M.; Talpur, K.H. and Talpur, N. (2016). Response of tomato (Lycopersicon esculentum L.) at varying levels of soil applied potassium. J. Basic \& Applied Sci., 12: 198-201.

Wuzhong, N. (2002). Yield and quality of fruits of solanaceous crops as affected by potassium fertilization. Better Crops International, 16(1): 6-8.

Zook, M.N.; Rush, J.S. and Kuc, J.C. (1987). A role for $\mathrm{Ca}^{2+}$ in the elicitation of rishitin and lubimin accumulation in potato tuber tissue. Plant Physiol., 84: 520-525. 


$$
\text { الملخص العربي }
$$

\section{استجابة نباتات الطماطم لمعدلات البوتاسيوم ومصادر الكالسيوم تحت ظروف الصوب البلاستيكية}

$$
\text { في شمال سيناء }
$$

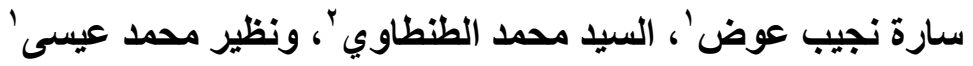

ا ـ قسم الزر اعة المحمية، مركز البحوث الزر اعية، القاهرة، مصر.

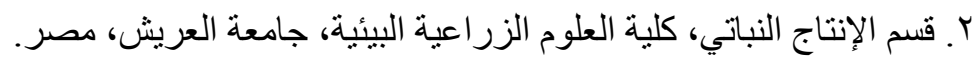

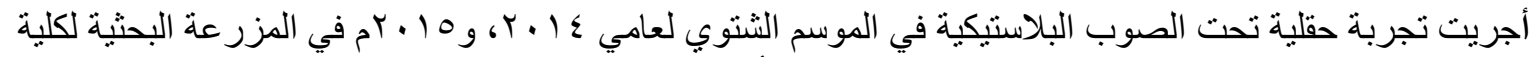

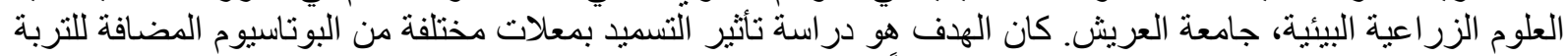

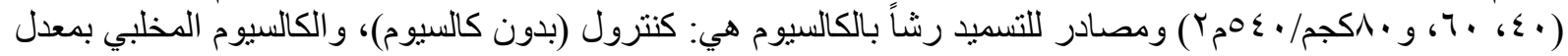

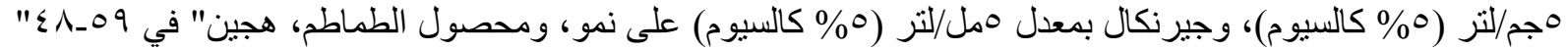

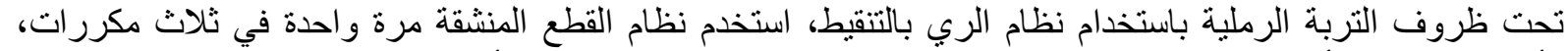

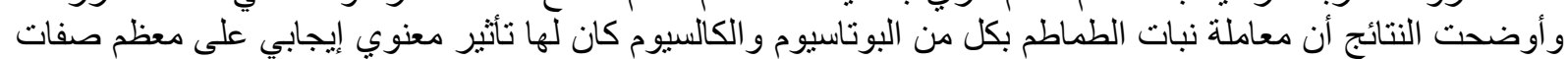

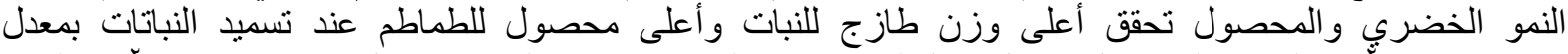

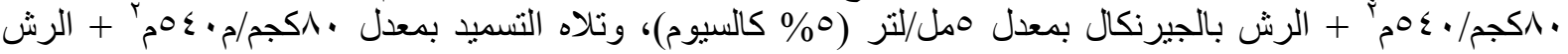

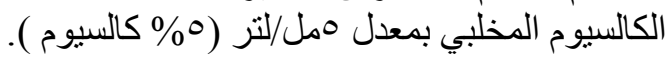

الكلمات الاسترشادية: الطماطم، الصوب البلاستيكية، مصادر البوتاسيوم و الكالسيوم، الوزن الطازج، المحصول الكلى. 
Awad, et al. 